\title{
Insight Arabic Teacher: The Challenges and Solutions to Arabic for Bidayuh's Pupils
}

\author{
Muhammad Safreen Shafie, Nik Mohd Rahimi Nik Yusoff, Harun Baharudin* \\ Fakulti Pendidikan, Universiti Kebangsaan Malaysia, Malaysia \\ Email: safreen.benyemin@gmail.com, *harunbaharudin5291@gmail.com
}

How to cite this paper: Shafie, M. S., Yusoff, N. M. R. N., \& Baharudin, H. (2019). Insight Arabic Teacher: The Challenges and Solutions to Arabic for Bidayuh's Pupils. Creative Education, 10, 2658-2670. https://doi.org/10.4236/ce.2019.1012193

Received: October 16, 2019

Accepted: November 25, 2019

Published: November 28, 2019

Copyright (อ 2019 by author(s) and Scientific Research Publishing Inc. This work is licensed under the Creative Commons Attribution International License (CC BY 4.0).

http://creativecommons.org/licenses/by/4.0/

(c) (i) Open Access

\begin{abstract}
Arabic language has been taught in Malaysian primary schools since 2005 and now, this language already spreads and reaches the non-Malay pupils including Bidayuh pupils. As for Bidayuh, this language is their foreign language whereby it took about their fifth place after their mother-tongue and other languages such as English and Bahasa Melayu Sarawak. By that, clearly it is a tough work to do for the teacher to teach this language. This paper will discuss qualitatively what are the challenges faced by the teacher to teach the Bidayuh's pupils Arabic. It is found that there are seven challenges that the teacher needs to resolve. This paper also seeks and highlights the reasons why it happens and suggests several solutions that relevant for the teacher to apply in order to make the lesson more interesting so the pupils are more excited to learn.
\end{abstract}

\section{Keywords}

Arabic Lesson, Learning and Teaching Lesson, Bidayuh Pupils, Foreign Language

\section{Introduction}

The real deal about Malaysia is that the variety of races and ethnicity living under one same roof of country whereby they all spent all the Malaysian's speciality together. Adding to that, all these varieties of races and ethnicity in Malaysia, they are all speaking in their own different languages. This leads to Malaysian's Ministry of Education to promote a variety of languages for the pupils in school to learn. Not only that, Malaysian education also offers foreign languages and one of them is Arabic (Akta Pendidikan 1996). Even though, this language is an alternative language subject to be taught in the schools throughout Malaysia, the majority primary schools in this country offer their pupils to learn Arabic. Despite having other languages subject to learn for example English, Chinese, 
Tamil, Kadazandusun, and Iban, Arabic stands out to be the foreign language of the most because apparently none of the Malaysian speak this language in their daily life conversation except for Muslims to perform their ibadah. The Arabic language is always perceived to be taught only to the Malay ethnic population (Aladdin, 2013) as all Malays in this country are a Muslim by religion. It is relatable due to our perspectives whereby Arabic language is more leaning towards understanding the Islamic faith. Thus, it became one of the objectives of learning Arabic language (e.g Rahman et al., 2017; Shukri et al., 2009; Zainur Rijal Abdul Razak \& Rosni Samah, 2007). Many scholars especially in Arabic language tried to focus on the issues about Arabic in schools, colleges and universities. This is due to the expand number of schools that offer this foreign language in the primary school throughout Malaysia (Aladin \& Musa, 2014; Mohd Fadzli Ismail \& Mohd Sukki Othman, 2012) whereby it is not only be taught to the Muslim's pupils only but it been taught to the non-Muslim's pupils as well. However, it still remains foreign language for all of us even though this language was already been taught in school since primary level (Rosni Samah, 2012; Nik Murshidah \& Normila Noruddin, 2011).

Since we step on $21^{\text {st }}$ century, there are a lot of research had been done regarding Arabic language in schools by our own researchers, which includes some of the latest research about teaching Arabic vocabularies (Irma Martiny Md Yasim et al., (2017); Baharudin (2014), Arabic learning technic (Hairun Najuwah Jamali et al., (2016); Sukardi et al. (2016)), teaching and learning problematic issues (Abdul Razif, (2018); Zaini et al. (2017)), Arabic speaking issues (Mohamad Ziyad Bin Mukhtar et al., (2017); Sopian (2016)) and even motivation towards Arabic language (Ghani \& Baharudin (2016); Abdullah et al. (2015)). By all means, these researches are meant to enhance and improve our Arabic language subject in schools. When we are looking at all of these researches' findings, everything will point to the role of teacher while teaching Arabic language subject whether it can be great, successful yet meaningful lesson or otherwise. This is because the teachers are the one who controls the lesson and transfers the knowledge from them to the students. The skills and the qualities of the teachers are very important because by having all these professionalism's vibes within themselves, the teachers can actually provide an effective yet quality teaching and learning session (Hyvärinen, Saaranen, \& Tossavainen, 2015). As for the Arabic language already been taught in school where Bidayuh's children are the pupils, the scope in Arabic educational field becomes wider in order to teach this language as their foreign language. Therefore, this research seeks the challenges faced by the Arabic teacher to teach the Bidayuh's pupils in primary school and tries to find a solution that might be a benefit to the teachers particularly and those who teach Arabic to other minority ethnic pupils.

\section{Methodology}

\subsection{Aim of the Study}

This study act as a reality check that focused on finding what are the challenges 
faced by the teacher who teach Arabic language to minority ethnic pupils, which Arabic language happened to be their foreign language. This study also seek for a solution proposed by the teacher to overcome this matter. The questions below constitute the foundation of the study;

1) How Arabic subject been selected and taught in primary school for Bidayuh's pupils from teacher's view of point from 4 different angles? The angles are as follow;

a) Teacher (him/herself)

b) Pupils

c) School's administrator/Headmaster/colleague

d) Parents

2) What are the challenges faced by the teacher in order to teach Arabic as foreign language to Bidayuh's pupils?

3) How to provide a solution and to overcome the challenges faced?

\subsection{Participant}

One primary school teacher who teach in one of the school in Bau district in Sarawak state was participated in this study. The teacher was chosen because the teacher was not an Arabic-optionist teacher to teach Arabic. The only thing that kept this teacher to have a courage and be able to teach this subject was that this teacher had learnt Arabic during high school ten years ago. Therefore, this female teacher (ustazah), who became the participant of this study been taught Arabic since she had been posted in this school six years ago. Since then, this teacher keep on learning or more likely recalling about Arabic language since she had left this language for a quiet sometimes. Since this explorational research is exploring on teacher's thought about Arabic language subject in primary school focusing on Bidayuh's pupils, therefore there was only one participant (teacher) was fully involved in order to gather the information regarding the views as an Arabic language subject teacher, school's administrator, pupils and their parents. To be clear, the study did not take the gender of their pupils and teachers into account.

\subsection{Instrumentation}

There were three instruments used in this study which were observation, interviews, and video recording. These three instruments were used for collecting the required data in this study.

\subsubsection{Observation}

The teacher was observed during the Arabic lesson in the classroom. The observation was done in order to determine and to participate in real life session to see the challenges that the teacher faced while teaching Arabic to the Bidayuh's pupils. In this study, two classes were observed which Year 2 class age 8 and Year 5 class age 11 years old. The observation then will be analysed accordingly. 


\subsubsection{Interviews}

The interviews were done with the teacher herself whereby several interviews were done in order to gain understanding about this matter and to collect the data required. The interviews will look through the teacher's point of views on herself, school's administration or headmaster, pupils and their parents. Furthermore, through interviews the teacher were asked a questions regarding the thought and personal opinions regarding this subject, the challenges and how the teacher tried to overcome the challenges mentioned by the teacher. Each view points from the teacher was expected to contribute to the solution of the problem. Through interview it was aimed to elicit how teachers deem the issue regarding challenges in Arabic language subject to Bidayuh's pupils.

\subsubsection{Video Recording}

Video recording was used in order to gain a better and bigger picture on how the Arabic subject was carried on in the classroom. The video recording was recorded by the teacher (participant) when she was teaching for these two particular reasons. The first reason was to fit for the absent of the researcher to the school in order to observe the lesson. By watching the video recording it helped the researcher to analyse the real-life when the lesson carried out. The decision of the absent while the lesson was carried out and using video recording was a good decision because it can record the real-life situation whereby all the pupils act normally as they always do in the classroom while learning rather than they might behave well and pretending to be a good pupils whenever the researcher or any other person observing them. By this, the researcher can gain much better understanding regarding the issue. For the second reason, the video recording was used for the sake of triangulation data. As this study a qualitative study, it is important for the researcher to analyse the data from various angles as it might play an important role in order to make sure the validity of this research.

\section{Data Analysis}

\subsection{Analysis of the Observation}

The classroom I attended was the class of 2 pupils from Bidayuh's ethnic age eight years old and also in other class sessions for 5 pupils' age eleven years old. The lesson was carried out not in the actual classroom but in one of the room provided by school to teach the Islamic subject. This due to the lack of numbers of pupils who took Arabic language as their foreign language in this school. The focus of this observation was to seek and gain information regarding Arabic language subject to Bidayuh's pupils and also to observed as a first party on what challenged the teacher to teach this subject for the minority ethnic pupils.

The first class that I observed was the Year 2 class where the pupils are age eight years old. The class started quiet warm even though the teacher was very good in order to start the lesson. This is due to the willingness of the pupils to stay focus on what the teacher is teaching and saying because the pupils keep looking at the researcher who sat at the back of the room. This was probably a 
rare thing for the pupils to see other person comes to their class and observe them while they are learning. When the lesson starts with a song, both of the pupils can sing the song probably because they always sing the song before the lesson. They look so eager to learn based on the energetic attitude showed while they sing. Then, the teacher will ask them about days and they manage to answer it even in one word about the day. The teacher then develops the lesson by asking in Arabic and both of them cannot answer it. They look each other and talk in Malay language to the teacher as they were guessing the meaning. When the delivery session, the teacher used two languages which were Arabic at first then the teacher will translate it to Malay language. The teacher keen to use the Malay language rather than Arabic even though she uses Arabic first. However, when she talked and explained in Malay language, she showed much eager to explain it rather than Arabic. This was probably the teacher still faced a lack of confident to use the language and maybe the teacher needs to explain in Malay language for the sake of the pupils to understand the lesson. The entire lesson was fine, where the teacher did activities for the pupils. When it comes to the speaking, answering questions, asking opinions, ask to read and any kind of act that requires the pupils to talk, they seem to hesitate and not really into participate. These can be a cause due to the ability to use the Arabic word, or maybe the lack of confidence in using the language or maybe the pupils were not so excited because there were only two of them, so they not really challenge each other. The lack of friends in this class shown when they always look for each other and know their turn to answer the questions or guessing something when the teacher was asking because it either me (pupil $A$ ) or him (pupil B) as for example. After a while, the pupils seems to calm a little bit whereby they not focusing on the researcher at the back anymore and start to look and focus to their teacher in front. From the observation, instead of difficulty to understand the language spoken by the teacher, the pupils always eager when they were provoke to guess or ask especially when the teacher knows how to grab their attention simply by changing the tone when she teach for example using high tone to make an excitement statement or using facial expression when asking or wondering something. Despite the lower achievement in this subject especially in speaking Arabic in their conversations, this positive attitude shown by the pupils when learn was something that can be an evidence that this language can be taught in primary school even to the minority groups of ethnicity like Bidayuh because Arabic is like other language in the world that is not impossible to be learnt.

After that, I manage to observe the second class which had 5 pupils, all Bidayuh age eleven years old. As much as previous class, the absent of me into the class quite a bit disturbing their attention and focus to the teacher in front. This class was not as energetic as previous class where the pupils sit calmly and barely answer the questions or giving feedback when the teacher asked even the teacher eagerly and teaching them with passion. This was probably because they found themselves a bit older or more mature since they are in Level 2 already and not really interest to join the lesson or became a bit childish when it comes to guess- 
ing the meaning and so on. The pupils also unmotivated and just read by repeating what the teacher read to them before. Despite the attitude of "macho" or "controlled" by the pupils, they still manage to do the activity together. From the observation, I can see that it is not them who not interest to learn this language, it is us as a teacher to be able to grab their attention by creating a creative yet suitable for them so they can participate eagerly in each lesson. The activity that involves sing a song was not really their interest since they were shy to sing a song while in the lesson. This probably because of me who sitting at the back of their class. However, I believe if the teacher can create an activity which need them to move and interview their friends, going out to find words or sentences such "Treasure Hunt", I think this might get their attention and it is suitable for their age which I personally think that they want the teacher to believe in them by giving them a task and let them be independent. However, despite all that, credit need to mention about the teacher whereby she tries so hard to build a positive environment and she did it. It was clear that she had a good relationship with the pupils. She respected them and made an effort not to make them feel humiliated and offended.

\subsection{Analysis of the Interview}

The discussion for each interview and responses of the teacher are discussed according to the parts as follows;

\section{Interview with the Teacher}

Before we begin to find out about the challenges and the suitable solution regarding Arabic subject in primary school for Bidayuh's pupils, the researcher needs to ask general information about this matter in order to understand why they need Arabic subject, and how this subject acceptance and influencing the Bidayuh's pupils.

The interview begins with the question that asks the opinion from the teacher about the suitability Arabic language in primary school for Bidayuh's pupils. The reason why these questions need to bring out was because, for Bidayuh, apparently Arabic language is totally foreign for the majority of the Bidayuh's people. Therefore, to seek for understanding about the suitability of these languages for them is important. From the interview, the teacher was positive towards teaching and learning Arabic language for the Bidayuh's pupils even in primary school. This is because the children at this age (in primary school) they will enjoy everything that they learn at school. She also mentions that even in her previous school, she taught Arabic to the Iban's pupils, and they also can learnt and scored in this subject. As for Bidayuh, learning Arabic can richer their knowledge about other things such as other culture, countries and more. This is a good opportunity for the pupils to learn more due to the geographical reason like their village located quite far from the city and also gives them a wider perceptions on learning the knowledge.

As for the school administration or headmaster, the school willing to promote 
this subject to the school to be taught in class. This is due to several factors. According to the teacher, the Arabic language was existed in the school around 2011 where there was an optionist teacher posted to this school. Since the school was already had Iban language as their alternative third language, so for Arabic language specially for all Muslim converted Bidayuh's pupils. This is because they believe that Arabic language more associated with the Islamic religion. Since then, Arabic language had been taught and even though there are only sixteen pupils age from seven to twelve who are Muslim converted Bidayuh, the subject still continuously taught.

For pupils, according to the teacher the younger the age is better because at this point of age, they willing to learn and participate eagerly in any kind of lessons including Arabic language. Even this subject is quiet difficult for them adding to the foreign language that maybe they never heard or spoke before, but they willing to learn and participate if there are been taught using interesting activities. Although teaching younger children might be difficult in terms of class control, preparing fun and easy lesson, however teaching level two pupils age ten to twelve is more challenging. At this age they didn't enjoy the lesson and they not really willing to participate especially when doing movement, or singing a song in Arabic. According to the teacher, this is because they not good in the language therefore, they feel shy to make mistakes and never try to use Arabic while in class. The other reason is probably they felt isolated because all of their friends are in the main classroom while only a couple of them move to the other room where Arabic subject taken place.

For the parents, all of them are converted Bidayuh and when they knew that their children will learn Arabic language at school, some of them felt relieved because they believe that Arabic is associated with Islam religion and this is such a good opportunity for them to learn more about Islam. Other parents also hope that one day their children can go to Islamic high school or religious school somewhere. However, not all the parents think the same thing. According to the teacher, some parents just don't even care about this matter as long as they manage to send their children to school and they learn something that is already good and enough for the parents.

\subsection{Analysis from the Video Recording}

The video recorded by the teacher herself when she was teaching in Year 2 class. From the recording, the teacher was a bit stiff at first while she was teaching probably because of the pressure by the assumption that she will be evaluated later but after a while, she manage to control and calmed herself and behave like normal. Judging by the behaviour of the pupils from the recording, it was totally different from what I observed last time. The pupils were so energetic from the first start of the lesson. The teacher starts her lesson by singing a song, which the same song like the last time I observed and I strongly believed that there is no wonder why the pupils can sing the song very well because the pupils repeated 
the same song every day. The lesson was fine as usual. One thing that capture my attention was the teacher was a dominant one where she always talk, asking questions, answering the questions, read and teach. On the other hand, even though the pupils did response but it was so minimal. The pupils did read the words and sentences but apparently they did not read, they just repeating what the teacher read to them. As for overall, the participation from the pupils was great but the lack of independent learning given by the teacher to her pupils was one of the issues that need to be brought up.

The second video was recorded while the teacher was teaching in Year 5 class. The pupils looked eager to learn. The lesson was fine but the pupils sometime looked unmotivated to participate especially when it came to speaking including answering and questioning session. From the recording, the pupils can repeat the lesson of what they had learn on that day but I am sure that they were not fully understood the knowledge they learnt, just a repeating it. It is because the pupils just repeat what the teacher said and even though the teacher provides a mix and match activity, still, they just repeating the lesson over again. Based on that activity, I assume that the pupils didn't learn anything much, just the content from the textbook and no cross-curriculum or some "outside" knowledge learnt.

\section{Findings}

Based on the analysis of the research including observation, interview and video recording, there are 7 challenges emerges that faced by the teacher when teaching Arabic. All these 7 challenges will be discussed.

\subsection{Challenge 1: Pupils' Behaviour towards Arabic Lesson}

Challenge: Pupils in Year 1 to 3 (aged 7 - 9 years old) are eager to learn. However, for those who are in the upper levels which are in Year 4 - 6 (aged 10 12 years old), most of them already started to show that they not really enjoy the lesson and not showing excitement when Arabic lesson especially when they are doing the activity.

Reasons: For the pupils in lower level (Year 1 - 3), there are a lot of possibilities which lead to the enjoyment of learning Arabic. One of them is that there are a lot of activities that can be carried out because there are more words or vocabularies to be learnt and the sentences are also not really that long which the pupils can still cope with it. For the upper lever pupils in Year 4 to 6, the reasons why they are showing unexcited to learn Arabic is because there are a lot of longer sentences and text that they need to learn, read and write especially those in Year 5 and 6. Besides that, learning "nahu" (Arabic grammar) makes them more reluctant to learn because they find it quiet hard to learn and always seeking for the answers given by the teachers whenever they are doing exercises.

Solution: For both parties (lower and upper level pupils), the teacher need to find and create more fun activities yet meaningful which might grab the pupils' 
attention. The language games which involve a movement would be good however, for a fewer number of pupils such like this particular school, the movement activity might not be the best solution. It is because for two pupils in class, it is better to have a board game or maybe creating a game which makes them need to discuss together so that will lighten the environment during the lesson. Besides that, teaching Arabic while making a poster, or craft or any relevant activities might be good since they are only a few numbers of pupils. The usage of song while teaching is good but somehow repeating the same song every time might get the pupils feel bored. Therefore, change the song regularly in order to keep the pupils interest and wanting more.

\subsection{Challenge 2: Pupils' Motivation towards Learning Arabic}

Challenge: Both pupils in lower and upper level are not keen towards learning this language. They always feel unmotivated and it shown by the reaction from them since they came to the class and when the teacher started to ask a questions.

Reasons: Both pupils in lower and upper level are keep thinking that Arabic lesson is not important. They also not see the importance and rational by learning this language at school since they know they never going to use this language in their daily life. They more focus on other subject especially math, science and English. Therefore, they always feel unmotivated to learn this subject.

Solution: The teacher must work very hard to make the pupils realise that Arabic is important subject as well as other subject they learn in the school. This can be done by always motivate them by telling a story of other people who can speak Arabic very well or can tell a story about the Prophet and his companions, other Islamic Scholars and more. Besides that, what the teacher can do to motivate the pupils is by giving them a relevant amount of knowledge in every lesson. This is due to how alien the pupils to Arabic and by doing so, the pupils can realise that Arabic is not that hard to learn. The teacher can also relate the lesson with the Quranic text to other issues that happened nationally or globally to show that Arabic is important as other subject as well and can be related to many things in our lives.

\subsection{Challenge 3: Pupils' Abilities to Communicate in Arabic Language}

Challenge: Generally pupils in this school have low ability to speak or to use Arabic. The pupils manage to greet, telling about the day, date and saying goodbye. However, they cannot use Arabic in order to complete one simple sentence in conversation either asking a question or answering question besides telling the day and date and greetings.

Reasons: For both parties (lower and upper level pupils), the main reason on why the pupils cannot use Arabic to communicate is because the teacher did not give them a maximum chance of opportunity to use the language. The teachers always try to translate into the Malay language while teaching Arabic. 
Solution: The teacher can try to use one hundred percent Arabic while teaching so that the pupils can be familiarise with this language. The teacher can use a simple shorter sentence in order to give orders, asking questions and even can use to explain the lesson. The use of teaching aid, and gestures might help the pupils to understand the lesson rather than translate it to their mother-tongue.

\subsection{Challenge 4: Pupils' Achievement in Arabic}

Challenge: Some pupils find it difficult and still cannot read in Arabic and some other fail this subject in their previous test. The remaining pupils in this school manage to cope and achieve a good result.

Reasons: For those who are managed to memorise the vocabularies, and what the teacher is teaching, and do some revise, they are able to pass and get a good result in their examination. However, for those who failed the test probably because they are not able to read the text, and not really care about the lesson because, all the questions are prepared by the same teacher and the questions were everything that they already learnt.

Solution: For the pupils who have difficulties in achieving a good result in their test, the teacher can guides these types of pupils personally because they might need extra-care from the teacher due to their slow-understanding and sometime they need more attention. Besides that, the teacher can collaborate with the parents to make sure that their child learn and doing the work given by the teacher. By making this collaboration with the parent, it will show the pupils that everybody is trying to help them to learn.

\subsection{Challenge 5: Creating Arabic Atmosphere (Surroundings, Support, Arabic Programme, Schools)}

Challenge: The pupils are not been exposed to much with the language unlike other subjects especially English.

Reasons: Only minority of pupils in this school learn Arabic. Therefore, they never use Arabic except during the lesson in the classroom only. There are also no Arabic programme had been done in the school due to these two reasons: first, because of the number of pupils who took Arabic are few, and second there is only one teacher who teaches Arabic and this particular teacher has no extra time to do so because she also teaches other subjects.

Solution: Regarding the lack of teachers who can teach Arabic in this school, the researcher cannot explain it any further since the deployment of the teachers is not in our hands. However, even though the teacher said she cannot make an Arabic programme in the school, since she has not extra time to make it, but she can create an Arabic environment in the school compound such as creating Arabic corner, or labelling every block or things in the school with Arabic. This way it not only promoting the language itself but it also creating the Arabic atmosphere in the school. Most important thing is it can be done and no need to make a "grand" programme in order to create the atmosphere. 


\subsection{Challenge 6: The Arabic Learning and Teaching Process (Teacher's Perspective)}

Challenge: Creating varieties of teaching aid.

Reasons: From the teacher herself, the major reason on why she cannot produce varieties of teaching aids and also planning an amazing lesson plan is because she had no time. She has forty period per week which mean she has to teach for the whole school time from morning until afternoon and only get thirty minutes rest every day due to recess time.

Solution: Again, the teaching period for each teacher is depending on the school and their administrator. Therefore, we cannot change it. However, in this case, the teacher can wisely think of the teaching aids that no need of extra work of making it. First for all, teaching aids are not only making something out of boxes, or paper but we can use anything that might gain understanding among the pupils. The teacher can use whatever she can find or maybe making activities that only require a pen, colour pencils and paper such as making a postcard and send it to their friends, teachers, or other pupils from other schools. Using smartphone to watch the video or using apps is also might help the teacher to create a good learning and teaching lesson since the fewer number of pupils in the class.

\subsection{Challenge 7: The Teacher's Competency}

Challenge: The teacher has lower competency in Arabic language including pedagogically, and struggling to learn the Arabic since she is not an optionist teacher.

Reasons: The teacher who is teaching Arabic in this school is non-optionist teacher. Since she teaches the Islamic Religion subject, the school ordered her to teach Arabic as well since she is the only Malay and a Muslim in the school. By that, she is struggling to learn on how to teach Arabic and at the same time leaning about the Arabic knowledge including the vocabularies (مفردات), grammar (نحو) and more.

Solution: The teacher can always consult with other teachers if there is a problem or if the teacher wants to share the idea for teaching. There are a lot of learning platforms in order to learn Arabic from the internet and nowadays it is not impossible to learn. For the teaching competency aspect, the teacher can relate the lesson to other lessons because teaching style is all the same, the only difference is the content. When teaching Arabic, the teacher can make a lot of activities which encourage the pupils to speak and use the language. The maximise usage of the language is not only for the pupils but the teacher as well. The teacher must fully use the language while teaching them so both parties can learn the language and at the same time can have confidence to use the language.

\section{Conclusion}

Teaching a foreign language to a minority ethnic group might get a challenge. 
However, it is all up to the teacher to face the challenge in a positive way or the other. The study of Arabic language to a minority ethnic group of pupils is still lacking and inadequate. The solution for the challenges provided from this research is the most relevant due to the several aspects including the location, status of the family, knowledge and the school's compound. In fact, empirical studies have not been specifically identified the best way of teaching foreign language to some minority ethnic groups of people, the strategies to be used and the best solution for each challenge faced by the teachers. However, many studies have proven innovative teaching strategies, or the use of innovative materials in teaching and learning can improve students' achievement and teacher quality (Tukimin et al. 2018). By that, it is clear that to face every challenge is by becoming an innovative teacher who can deal with their surroundings accordingly and manage to motivate their pupils to learn and have confidence with it. A more in-depth study like this case study needs to be explored to review about the Bidayuh's pupils in order to teach and learn the Arabic language from different perspectives. Hopefully the practices of the solutions can be applied especially to Arabic teachers who teach Arabic or any other foreign language to the minority group of ethnic in the rural area. It is also as one of the contributions to the improvement of the quality of educational services.

\section{Acknowledgements}

This research was supported by grand received from the Faculty of Education, Universiti Kebangsaan Malaysia code PP-FPEND-2019 and GG2019-026. With that, I would like to express my grateful to the editors of Learning \& Technology for this opportunity. My sincere gratitude to Dr. Harun Baharudin of National University of Malaysia for his guidance and support in the writing of this manuscript and to Faculty of Education, UKM. I would also express my gratitude to all the staff of this school especially the teacher who was involved in this research which their contributions were essential.

\section{Conflicts of Interest}

The authors declare no conflicts of interest regarding the publication of this paper.

\section{References}

Abdullah, A. H., Sulaiman, Ab. A., \& Abdullah, W. I. W. (2015). Faktor-Faktor Yang Mempengaruhi Motivasi Terhadap Pembelajaran Bahasa Arab. Jurnal Islam dan Masyarakat Kontemporari, 10, 104-121.

Aladdin, A. (2013). Demotivating Factors in the Arabic Language Classroom: What Demotivates Non-Muslim Malaysian Learners When It Comes to Learning Arabic? Procedia-Social and Behavioral Sciences, 93, 1652-1657.

https://doi.org/10.1016/j.sbspro.2013.10.096

Aladin, A., \& Musa, N. (2014). Arabic Language Courses for Student at the Faculty of Law UKM-Importance and Challenges. Procedia-Social and Behavioral Sciences, 118, 
51-55. https://doi.org/10.1016/i.sbspro.2014.02.007

Baharudin, H. (2014). Strategi Pembelajaran Kosa Kata Bahasa Arab Pelajar Sekolah Menengah Agama di Malaysia. PhD Thesis, Kuala Lumpur: University of Malaya.

Ghani, F., \& Baharudin, H. (2016). Pendekatan “Mobile Learning” Dalam Meningkatkan Motivasi Pelajar.

Hyvärinen, K., Saaranen, T., \& Tossavainen, K. (2015). A Teacher's Professional Competence and Occupational Well-Being-A Survey for Finnish Health Care Sector Teachers. In ECER 2015 (pp. 1-3). Berlin: European Educational Research Association.

Ismail, M. F., \& Othman, M. S. (2012). Faktor-Faktor Yang Mempengaruhi Pencapaian Pelajar Dalam Pengajaran \& Pembelajaran Bahasa Arab: Satu Tinjauan Di SMAP Kajang. Bangi: Universiti Kebangsaan Malaysia.

Jamali, H. N., Rahman, A. A., Azizan, K. F. K., \& Isa, S. N. Md. (2016). Membina Kemahiran Bertutur Dalam Bahasa Arab Melalui Teknik Main Peranan. e-Journal of Arabic Studies \& Islamic Civilization, 3, 89.

Md Yasim, I. M., Lubis, M. A., Noor, Z. A. M., \& Sjahrony, A. (2017). ASEAN Comparative Education Research. Journal on Islam and Civilization, 1, 14-24.

Mukhtar, M. Z. B., \& Damit, S. Ag. (2017). Aplikasi Lughat al-Faṣl dalam Pengajaran Bahasa Arab Using Lughat al-Fașl in Teaching Arabic Language. MANU Bil, 26, 153-183.

Murshidah, N., \& Noruddin, N. (2011). Penerepan Aspek Bahasa, Budaya dan Pendidikan Terhadap Buku Teks Bahasa Arab Dalam Program jQAF. Jurnal Islam dan Masyarakat Kontemporari Jilid, 4, 27-4.

Rahman, A. A., Isa, S. N. Md., Hamidin, M. M., \& Hamdi, I. (2017). Refleksi Keperluan Modul Bahasa Arab Di Peringkat Prasekolah. In e-Proceeding of the 5th Global Summit on Education 2017 (pp. 54-59). Kuala Lumpur, Malaysia.

Razak, Z. R. A., \& Samah, R. (2007). Kesan Bahasa Arab Dalam Peradaban Melayu di Malaysia. Negeri Sembilan: Kolej Universiti Islam Malaysia.

Samah, R. (2012). Arabic Sentences Constructions among the Islamic Religious School Graduates. GEMA Online Journal of Language Studies, 12, 555-569.

Shukri, K., Amin, M., Rahimi, N. M., \& Mahamod, Z. (2009). Strategi Metafizik: Kesinambungan Penerokaan Domain Utama Pembelajaran Bahasa. GEMA Online Journal of Language Studies, 9, 1-13.

Sopian, A. (2016). Tahap Pertuturan Bahasa Arab Dalam Kalangan Pelajar yang mengambil Kursus Bahasa Arab di Uitm Melaka. In e-Proceeding of the 3rd International Conference on Arabic Studies and Islamic Civilization (pp. 174-187). Kuala Lumpur, Malaysia.

Sukardi, R., Baharudin, H., \& Lubis, M. (2016). Konsep Gamification Sebagai Kaedah Meningkatkan Motivasi Dalam Pembelajaran Bahasa Arab Di Malaysia. Kolokium Pendidikan Bahasa Arab 2016 (KOBAR '16).

Tukimin, R., Yusoff, N. M. R. N., Baharudin, H., \& Hussain, F. (2018). Innovative Arabic Language Teacher: A Dream or a Hope. International Journal of Academic Research in Progressive Education and Development, 7, 158-165.

Zaini, A. R., Zakaria, N. S., Ghazali, A. R., Ismail, M. R., Hamdan, H., Razak, A. Z. A., Azizan, R., \& Mansor, N. (2017). Kompetensi Guru Bahasa Arab Dalam Pengajaran Bahasa Arab Di Sekolah Rendah Kementerian Pendidikan Malaysia. Laporan Geran Penyelidikan Inovasi KUIS 2016.

Zaini, A., Redzaudin, M., Ismail, R., Zakaria, N., Hamdan, H., \& Rushdan, M. (2017). Permasalahan Pengajaran Dalam Bahasa Arab Di Malaysia. 